\title{
Impact of Shading of a Silvopastoral System on Microclimate and Botanical Composition of Polyphytic Pasture: A Preliminary Study in the Subtropics
}

\author{
Frederico Márcio C. Vieira ${ }^{*}$, Érica R. Militão ${ }^{1}$, Américo Wagner Júnior², Piotr Herbut ${ }^{3}$, \\ Lilian Regina R. Mayer², Edgar S. Vismara², Afrânio Márcio C. Vieira4 ${ }^{4}$, Wagner Paris², \\ Cátia Hermes' ${ }^{1}$ Iwona Paśmionka ${ }^{5}$
}

1 Biometeorology Study Group [GEBIOMET], Universidade Tecnológica Federal do Paraná [UTFPR], Estrada para Boa Esperança, km 04, Comunidade São Cristóvão, Dois Vizinhos, Paraná, Brazil

2 Universidade Tecnológica Federal do Paraná [UTFPR], Estrada para Boa Esperança, km 04, Comunidade São Cristóvão, Dois Vizinhos, Paraná, Brazil

3 Department of Rural Building, Faculty of Environmental Engineering and Land Surveying, University of Agriculture in Krakow, 31-120 Kraków, Poland

${ }^{4}$ Department of Statistics, Federal University of São Carlos, 13565-905 São Carlos, Brazil

${ }^{5}$ Department of Microbiology and Biomonitoring, Faculty of Agriculture and Economics, University of Agriculture in Krakow, 31-120 Kraków, Poland

* Corresponding author's e-mail: fredericovieira@utfpr.edu.br

\begin{abstract}
The silvopasture system is an integrated system which has been widespread in tropical and sub-tropical climates. However, there is a lack of detailed studies regarding agroecological silvopasture systems. This study assessed whether the different levels of shading in an agroecological silvopastoral system influences the microclimate and botanical composition of polyphytic pasture. We used eight paddocks composed of a silvopastoral system in a subtropical climate, with different tree species arranged in simple lines with polyphytic pasture. In each paddock, we established three levels of visual shading (under the canopy, intermediate and full sun). The following microclimatic variables were recorded monthly during the daytime: illuminance, air temperature, air relative humidity, wind speed, and surface soil temperature. The samples of forages were separated into grasses, legumes and spontaneous, then fractionated into leaves, stems, and senescent material. We observed lower values of illuminance and surface soil temperature under the canopy, with differences between full sun and under the canopy at noon. Regarding the forage, the percentage of legumes was higher in full sun, and spontaneous species and leaves had high proportions under the canopy. Based on the results, the agroecological silvopastoral system changed the microclimatic characteristics and altered the plant composition of polyphytic pasture.
\end{abstract}

Keywords: integrated crop-livestock-forest systems, biometeorology, shading, polyphytic grassland

\section{INTRODUCTION}

The livestock grazing has a large territorial extension in tropics and subtropics as a low-cost system for maintenance and implementation [Poppi et al., 2018]. However, approximately $33 \%$ of the world terrestrial surface have some degree of degradation [Wall and Six, 2015], resulting in reduced productivity and damage to soil resources, such as erosion and leaching of soil nutrients. In this context, the adoption of practices that promote the sustainability and conservation of natural resources is necessary to mitigate degradation effects.

Ergo, agroecology is strengthened, focused on agronomic, ecological, and socio-economic studies in agricultural systems [Altieri, 2018]. According to the same author, the agroecology 
associated with the production model that resembles natural ecosystems - such as agroforestry - is an alternative to achieve sustainability in agricultural production and pasture areas. The silvopastoral system is an agroforestry arrangement that integrates into the same area, simultaneously, the use of pastures, trees, and animals [Peri et al., 2016] to change microclimate conditions for the benefit of the environment and consequently for animal production [Vieira et al., 2020]. This system becomes essential for animal thermal comfort because the shade of the trees reduces the thermal load of the environment providing adequate conditions for grazing animals [Karvatte Jr. et al., 2021].

The trees support animal production and contribute to improvements in forage production if the vegetal species are introduced correctly. The mulch from the trees directly increases the production of soil biomass, which raise the level of soil organic matter [Murgueitio et al., 2014]. However, if this system is not correctly managed, the effects may be harmful.

The densification of trees can cause a high reduction of solar radiation above the forage canopy, which changes the illuminance and the temperature, impairing photosynthesis and leading to problems in animal production because the forage requires a suitable environment for growth and development [Feldhake, 2009]. Therefore, adequate criteria are necessary regarding the choice of tree species, the distance between individuals, and forest management to ensure the successful implementation of the silvopastoral system [Jose and Dollinger, 2019].

In this system, microclimatic differences may occur within the same site, which emphasizes the importance of characterizing such changes and quantifying them in the evaluated system. However, we found a lack of studies regarding the microclimatic variation in an agroecological silvopastoral system. Thus, it is essential to evaluate the microclimate provided by the composition of different trees and their influence on the quality and production of polyphytic pasture in a silvopastoral system managed in an agroecological design. It is necessary before introducing grazing animals, to understand the conditions of microclimate in different points, such as under the canopy and in full sun. It is also important to evaluate the effect on the botanical composition and morphologic characteristics of plants. Thus, we aimed to assess whether the different levels of shading in an agroecological silvopastoral system influences the microclimate and botanical composition of polyphytic pasture.

\section{METHODS}

\section{Study area}

A trial was carried out at the Centro Paranaense de Referência em Agroecologia (Paraná Center for Reference in Agroecology - CPRA), in the city of Pinhais, Paraná State, Brazil. The geographic coordinates were $25^{\circ} 23^{\prime} 06.21^{\prime \prime} \mathrm{S}$ and $49^{\circ} 07^{\prime} 26.16^{\prime \prime} \mathrm{W}$, with an altitude of 893 meters above sea level. According to the Köppen classification, the climate of the region is $\mathrm{Cfb}$, humid subtropical (Mesothermal), with an average temperature of $11^{\circ} \mathrm{C}$ in the coldest month, sometimes reducing below $2{ }^{\circ} \mathrm{C}$. During the summer, the average temperature is approximately $23^{\circ} \mathrm{C}$, and it can reach above $32^{\circ} \mathrm{C}$ [Alvares et al., 2014].

The studied site was composed of an agroecological silvopastoral system, established over 10 years ago (Figure 1).

Pasture is polyphytic, composed of several species of grasses, such as Axonopus compressus (Sw.) P. Beauv., Pennisetum clandestinum Hochst. Ex. Chiov., spontaneous species, and by legumes, with a predominance of Trifolium repens L. and Arachis pintoi K. Regarding the trees, the species found in the experimental area was Mimosa scabrella Bentham; Hook., Lafoensia pacari SaintHilaire, Psidium cattleianum Sabine, Bastardiopsis densiflora (Hooker \& Arnott) Hassler, Fedde, Taxodium distichum (L.) Rich., Liquidambar styraciflua L., Compomanesia cambessedeana Berg. and Acer palmatum Thunb. The following inventory is showed in Table 1.

The paddocks handling was carried out by the mob-grazing, in which grazing occurs with high stocking and grazing time is short, and the animals were used only for lowering the forage canopy. The lactating cows of this system are Jersey $\mathrm{x}$ Holstein crossbred $(\mathrm{n}=27)$, with age varying between 34 to 63 months, body weight average of $410 \mathrm{~kg}$ and days in milk average of 128 .

The animals were moved when the forage was grazed down to a height of 6 to $8 \mathrm{~cm}$. The mean grazing intervals were 28.9 days. Nine pasture samples per paddock were collected to determine 


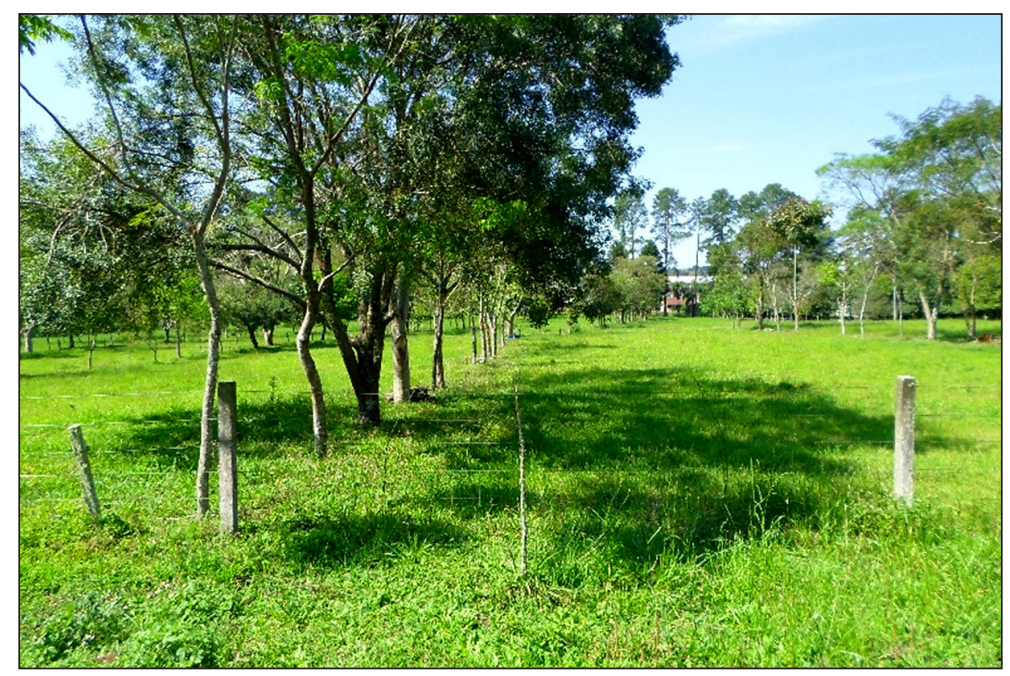

Figure 1. View from the experimental area

the dry matter, botanical composition, and structural constituents. These samples were collected in three levels of shade in the paddock (under the canopy, intermediate, and full sun).

The soil of the experimental area was classified as typical dystrophic Cambisol with humic horizon B. For a better understanding of the studied area, soil samples were collected for chemical analysis (Table 2).

The samples were collected in a zig-zag pattern, totaling 4 samples of $0-20 \mathrm{~cm}$ per paddock, totaling 24 samples. Chemical analyses were carried out at the Soil Laboratory of the "Luiz de Queiroz" College of Agriculture (ESALQ/USP).

As for soil analysis, the soil was generally presented with high organic matter with more than $50 \mathrm{~g} \mathrm{dm}^{-3}$ and $\mathrm{pH}$ varying between average acidity and no acidity, but not compromising the soil. Base saturation was acceptable on all paddocks. The potassium content was high in all pickets, but phosphorus levels vary between low and very low.

\section{EXPERIMENTAL DESIGN}

We used for the study eight paddocks with an average of $898.75 \mathrm{~m}^{2}$ of area. The system was composed of trees of different species, arranged in simple lines with an average spacing of $2.5 \mathrm{~m}$ between individuals.

For microclimatic recordings, we performed the measurements at three different times, the first time from 8:00 am to 10:00 am, the second time from $12: 00 \mathrm{pm}$ to $2: 00 \mathrm{pm}$ and the third time from 4:00 pm to 6:00 pm, with an interval of one hour for each observation.

With the paddocks established, the points of microclimatic data recordings within the paddocks were determined according to the level of visual shading provided by the silvopastoral system. We measured three points per level, inside each paddock. The levels were defined as follows:

- Level 1: under the canopy of the trees (the point that entirely remains the shade for most of the day);

Table 1. Forest inventory of the tree individuals on the studied paddocks

\begin{tabular}{|c|c|c|c|c|c|c|c|}
\hline $\mathrm{N}^{\circ}$ paddock & $\begin{array}{c}\text { Number of } \\
\text { trees }\end{array}$ & Average DBH & TH & HF & $\begin{array}{c}\text { Average } \\
\text { canopy rays }\end{array}$ & $\begin{array}{c}\text { Shading area } \\
\left(\mathrm{m}^{2}\right)\end{array}$ & $\begin{array}{c}\text { Total paddock } \\
\text { area }\end{array}$ \\
\hline 10 & 14 & 14.53 & 9.15 & 3.62 & 4.60 & 85.33 & 938.12 \\
\hline 11 & 19 & 14.92 & 9.08 & 2.49 & 4.34 & 82.98 & 946.36 \\
\hline 12 & 12 & 18.70 & 8.41 & 2.66 & 5.21 & 108.17 & 812.70 \\
\hline 13 & 18 & 18.01 & 7.86 & 2.83 & 5.38 & 107.41 & 852.77 \\
\hline 07 & 15 & 14.74 & 8.70 & 2.83 & 3.91 & 61.43 & 830.07 \\
\hline 06 & 17 & 14.06 & 6.68 & 2.33 & 4.05 & 62.61 & 928.57 \\
\hline 05 & 14 & 14.48 & 6.17 & 1.74 & 4.05 & 77.35 & 897.31 \\
\hline 04 & 15 & 16.28 & 7.08 & 2.70 & 4.40 & 88.21 & 984.07 \\
\hline
\end{tabular}

DBH: diameter of breast height; TH: total height; HF: height of the first fork 
Table 2. Forest inventory of the tree individuals on the studied paddocks

\begin{tabular}{|c|c|c|c|c|c|c|c|c|c|c|c|c|}
\hline \multirow[t]{2}{*}{$\mathrm{N}^{\circ}$ paddock } & \multirow{2}{*}{$\begin{array}{c}\mathrm{pH} \\
\mathrm{CaCl}_{2}\end{array}$} & \multirow{2}{*}{$\begin{array}{l}\text { O.M. } \\
\text { Col. } \\
\mathrm{g} \mathrm{dm}^{-3}\end{array}$} & $P$ & $\mathrm{~K}$ & $\mathrm{Ca}$ & $\mathrm{Mg}$ & $\mathrm{H}+\mathrm{Al}$ & $\mathrm{Al}$ & BS & CEC & V & $\mathrm{m}$ \\
\hline & & & \multicolumn{2}{|c|}{$\mathrm{mg} / \mathrm{dm}^{-3}$} & \multicolumn{6}{|c|}{$\mathrm{cmol}_{\mathrm{c}} / \mathrm{dm}^{-3}$} & \multicolumn{2}{|c|}{$\%$} \\
\hline 10 & 4.7 & 58.1 & 7.8 & 104 & 5.8 & 2 & 14.2 & 1 & 8.1 & 22.3 & 36.3 & 10.99 \\
\hline 11 & 4.8 & 58.4 & 4.3 & 129 & 6.5 & 2.4 & 13.7 & 0.7 & 9.2 & 22.9 & 40.2 & 7.07 \\
\hline 12 & 5.1 & 57.8 & 7.1 & 154 & 7.8 & 4.5 & 11.2 & 0.1 & 12.7 & 23.9 & 53.1 & 0.78 \\
\hline 13 & 4.9 & 57.5 & 17.3 & 172 & 6.7 & 2.8 & 11.6 & 0.3 & 9.9 & 21.5 & 46 & 2.94 \\
\hline 04 & 5.4 & 56.5 & 10.7 & 205 & 12 & 4.2 & 7.5 & 0 & 16.7 & 24.2 & 69 & 0 \\
\hline 05 & 5.6 & 50.4 & 5.2 & 175 & 12.8 & 4.3 & 6.5 & 0 & 17.5 & 24 & 72.9 & 0 \\
\hline 06 & 6.5 & 55.5 & 5.4 & 162 & 12.9 & 5.7 & 3.2 & 0 & 19 & 22.2 & 85.6 & 0 \\
\hline 07 & 5.2 & 55.9 & 6.5 & 212 & 10.9 & 2.8 & 8.9 & 0 & 14.2 & 23.1 & 61.5 & 0 \\
\hline
\end{tabular}

$\mathrm{pH} \mathrm{CaCl}_{2} .:$ hydrogen potential in calcium chloride; O.M. Col.: Organic matter by colorimetry; P: phosphorus; $\mathrm{K}$ : potassium; $\mathrm{Ca}$ : calcium; $\mathrm{Mg}$ : magnesium; $\mathrm{H}+\mathrm{Al}$ : potential acidity; $\mathrm{Al}$ : aluminum; $\mathrm{BS}$ : base saturation; $\mathrm{CEC}$ : cation exchange capability; V: base saturation; m: aluminum saturation.

- Level 2: intermediate (an area that remains in a transition place shade and sun during the day);

- Level 3: in full sun (the place that remains in full sun throughout the day).

\section{MICROCLIMATE ANALYSIS}

All microclimatic measurements were undertaken once a month for 10 months (from December 2015 to September 2016). The illuminance (lux), air temperature $\left({ }^{\circ} \mathrm{C}\right)$, air relative humidity $(\%)$, wind speed ( $\mathrm{m} \mathrm{s}-1)$ and soil surface temperature $\left({ }^{\circ} \mathrm{C}\right)$ were evaluated. Except for soil surface temperature, all the measurements were taken $1.50 \mathrm{~m}$ above the soil. For air temperature, relative humidity, and wind speed, we used a thermohygro-anemometer ITAN 700 (Instrutemp, São Paulo, Brazil). Regarding the illuminance, we measured using a digital lux meter, model LDR225 (Instrutherm, São Paulo, Brazil). The soil surface temperature was recorded with the use of an infrared thermometer, model TI-870 (Instrutherm, São Paulo, Brazil).

\section{Botanical composition}

Within each paddock, nine forage samples were collected, referring to the points and ranges established in the experimental design.

The forage was collected with a metallic square with dimensions of $25 \times 25 \mathrm{~cm}$. This metallic square was randomly released at the points. The forage was cut as closest to the ground as possible with the aid of pruning shears and stored in previously identified paper bags. After collection, the samples were weighed to obtain the fresh matter mass of the forage and then kept under refrigeration for subsequent separation of botany and structural constituents. The average height of the plant was measured with a graduated ruler at a point within the metallic square, considering the plants with observed average height.

As for botanical separation, the pasture sample collected was separated into the grass, legumes and spontaneous (species that were not intentionally established). After determining the proportion of each species (grass and legume) in the sample, it was divided into leaves (leaf blades), stems and senescent material (considering the material with more than $50 \%$ visibly senescent) and proceeded to dry in a forced-air oven at $55^{\circ} \mathrm{C}$ for 72 hours to determine the dry matter of the structural constituents. The leaf/stem ratio was expressed as the ratio between $\mathrm{kg}$ ratio of leaf $\mathrm{kg}$ of stem ${ }^{-1}$.

\section{STATISTICAL ANALYSIS}

The statistical analysis for climate variables was based on linear mixed models, assuming the following mathematical model:

$$
y=\mu+\alpha+b+\tau+\psi+\tau \psi+\varepsilon
$$

where: $y$ is a $1944 \mathrm{x} 1$ response vector;

$\mu$ is a common effect vector to all observations;

$\alpha$ is the month effect, assuming the values $\{1, \ldots, 9\}$;

$b$ is the paddocks random effect vector, assuming $b \sim N_{8}\left(0, \sigma_{b}^{2} I\right)$; 
$\tau$ is the daily hours period effect vector, assuming the values $\{1,2,3\}$;

$\psi$ is the illuminance levels points effect vector, assuming the values $\{1,2,3\}$;

$(\tau \psi)$ is the daily hour period/illuminance levels points interaction effect vector;

$\varepsilon$ is a random error term, $\varepsilon \sim N\left(0, \sigma^{2} I\right)$. The mathematical model for botanic variables follows:

$$
y=\mu+\alpha+b+\psi+\alpha \psi+\varepsilon
$$

where: $y$ is a response vector;

$\mu$ is a common effect vector to all observations;

$\alpha$ is the month effect, assuming the values $\{1, \ldots, 9\}$;

$b$ is the paddocks random effect vector, assuming $b \sim N_{8}\left(0, \sigma_{b}^{2} I\right)$;

$\psi$ is the illuminance levels points effect vector, assuming the values $\{1,2,3\}$;

$(\alpha \psi)$ is the month/illuminance levels points interaction effect vector;

$\varepsilon$ is a random error term, $\varepsilon \sim N\left(0, \sigma^{2} I\right)$.

The inference over the fixed effects was based on likelihood ratio tests using the usual asymptotic large sample sampling distributions when the normal distribution assumption was adherent [Verbeke and Molenberghs, 2000]. In the cases where the error residuals were not normally distributed, randomized permutation tests (or Monte Carlo permutation tests) was adopted [Lee and Braun, 2011]. These tests are nonparametric tests, robust to nonnormality, heteroscedasticity or sample size restriction. The only strong assumption is the exchangeability of observations under the null hypothesis, which are guaranteed by the executed experimental planning. The drawback is the computer-intensive calculations, where for each test, it was set 9999 random permutations to generate the sampling distribution for test statistics, demanding some hours for all the calculations. Confidence intervals and p-values for multiple comparisons were based on Bonferroni adjustment to $p$-values, to control the Type-I errors. Residual diagnostics supported the choice when to adopt the normal-based likelihood tests or Monte Carlo permutation tests. All statistical procedures were performed through the $\mathrm{R}$ software [R Development Core Team, 2019].

\section{RESULTS}

\section{Microclimate}

We observed an interaction between daily hours vs points $(\mathrm{P}<0.001)$ for illuminance (Table 3). In the full sun, the illuminance was lower at 16:00 to 18:00 when compared to the other periods. Under the canopy, the higher illuminance was recorded from 12:00 to 14:00, followed by 08:00 to 10:00. Comparing the shading levels, the lowest illuminance was obtained under the canopy during all daily periods, as described in Table 1. However, at 08:00 to 10:00 and 16:00 to 18:00, the mean value of illuminance obtained in the full sun was similar to the intermediate point.

Regarding the average variation of soil surface temperature, there was an interaction between hours vs points $(\mathrm{P}<0.001)$ (Table 4). The higher soil surface temperatures were obtained in the intermediate level and full sun for 12:00 to $14: 00$. Also, we found higher values under the canopy and in the intermediate point at 16:00 to 18:00. According to each shading level, the higher soil surface temperature in the silvopastoral system was obtained from 12:00 to 14:00. Our results demonstrated the effect of shading by trees in an agroecological system to maintain the soil surface temperature lower along the day. This effect is important to increase soil microbial activity, which results in benefits to soil and rhizosphere.

Considering the air temperature, our results showed that there was no interaction between hours vs shading levels $(\mathrm{P}=0.8866)$. However, daily hours had a significant effect $(\mathrm{P}<0.001)$. As expected, for the assessed time intervals, the air temperature was higher at noon, and the lowest mean temperature was found under the canopy (Table 5).

The amplitude of values between 8:00 to 10:00 and 12:00 to $14: 00$ was higher, with $5.8^{\circ} \mathrm{C}$. Between 12:00 to $14: 00$ and 16:00 to $18: 00$, we found an amplitude of $4.4{ }^{\circ} \mathrm{C}$. The higher amplitude between the first intervals is due to the linear increasing of air temperature with solar radiation.

There was no interaction between hours vs points for relative humidity $(\mathrm{P}=0.9771)$ and wind speed $(\mathrm{P}=0.5305)$. However, the significative effect was obtained for time intervals $(\mathrm{P}<0.001)$. Concerning the air relative humidity, the lowest average was recorded at 12:00 to 14:00, and the 
Table 3. Illuminance values (lux) according to different distances from the canopy of the silvopastoral system and times of the day

\begin{tabular}{|c|c|c|c|}
\hline \multirow{2}{*}{ Points } & \multicolumn{3}{|c|}{ Hours } \\
\cline { 2 - 4 } & $8: 00-10: 00$ & $12: 00-14: 00$ & $16: 00-18: 00$ \\
\hline Under the canopy & $13.083 .0 \mathrm{Bb}^{1}$ & $15.267 .1 \mathrm{Ca}$ & $5.766 .5 \mathrm{Bc}$ \\
\hline Intermediate & $25.764 .5 \mathrm{Ab}$ & $36.900 .7 \mathrm{Ba}$ & $10.421 .0 \mathrm{Ac}$ \\
\hline Full sun & $32.807 .5 \mathrm{Ab}$ & $58.015 .7 \mathrm{Aa}$ & $13.197 .3 \mathrm{Ac}$ \\
\hline
\end{tabular}

${ }^{1}$ Means followed by the same upper-case letters on the columns and lower-case letters in the lines did not differ in the Bonferroni test, at 5\% probability.

Table 4. Soil surface temperature values $\left({ }^{\circ} \mathrm{C}\right)$ according to different distances from the canopy of the silvopastoral system and times of the day

\begin{tabular}{|c|c|c|c|}
\hline \multirow{2}{*}{ Points } & \multicolumn{3}{|c|}{ Hours } \\
\cline { 2 - 4 } & $8: 00-10: 00$ & $12: 00-14: 00$ & $16: 00-18: 00$ \\
\hline Under the canopy & $17.7 \mathrm{Bc}^{1}$ & $21.2 \mathrm{Ca}$ & $19.8 \mathrm{Ab}$ \\
\hline Intermediate & $19.3 \mathrm{Ac}$ & $24.0 \mathrm{Ba}$ & $20.4 \mathrm{ABb}$ \\
\hline Full sun & $19.6 \mathrm{Ac}$ & $26.1 \mathrm{Aa}$ & $21.0 \mathrm{Bb}$ \\
\hline
\end{tabular}

${ }^{1}$ Means followed by the same upper-case letters on the columns and lower-case letters in the lines did not differ in the Bonferroni test, at 5\% probability.

higher was found during 8:00 to 10:00. There was a $17 \%$ reduction in the humidity value from $12: 00$ to $14: 00$ and $10 \%$ from $16: 00$ to $18: 00$. The wind speed was lower in the first hours, from 8:00 to $10: 00$, and at dusk, from 16:00 to $18: 00$, compared to the time of highest peak solar radiation and temperature, 12:00 to 14:00. At 12:00 to 14:00, an average of $0.5 \mathrm{~m} \mathrm{~s}^{-1}$ was registered, with an increase of $0.3 \mathrm{~m} \mathrm{~s}^{-1}$ compared with other intervals (Table 5).

\section{Botanical composition}

We found differences between the shading levels regarding the proportions of legumes and spontaneous species (Table 6).
The proportion of legumes was lower under the canopy than the other shading levels. This could be caused by the lowest illuminance (Table 3) and soil surface temperature (Table 2), which influence the plant metabolism and soil microbial activity. For the botanical components, we observed difference between shading levels, mainly for the proportions of grass leaf and leaf/ stem ratio (Table 7).

For leaf proportions and leaf/stem ratio of grass, the mean value was higher under the canopy when compared with other shading levels.

The legumes plant did not show the same morphological answer (Table 6) due to the preference for growth in the condition of the lowest illuminance (Table 3 and 7).

Table 5. Descriptive statistics (mean \pm standard deviation, minimum median and maximum) for the variables of microclimate during selected hours.

\begin{tabular}{|c|c|c|c|c|c|}
\hline Variables & Hours & Mean & Minimum & Median & Maximum \\
\hline \multirow{3}{*}{ Temperature $\left({ }^{\circ} \mathrm{C}\right)$} & $8: 00-10: 00$ & $23.6 \pm 7.1 \mathrm{c}^{1}$ & 14.2 & 28.8 & 39.0 \\
\cline { 2 - 6 } & $12: 00-14: 00$ & $29.4 \pm 6.7 \mathrm{a}$ & 18.5 & 28.9 & 42.0 \\
\cline { 2 - 6 } & $16: 00-18: 00$ & $25.0 \pm 6.1 \mathrm{~b}$ & 14.1 & 24.7 & 38.9 \\
\hline \multirow{3}{*}{ Relative humidity (\%) } & $8: 00-10: 00$ & $66 \pm 16 \mathrm{a}$ & 32 & 69 & 89 \\
\cline { 2 - 6 } & $12: 00-14: 00$ & $49 \pm 16 \mathrm{c}$ & 20 & 49 & 89 \\
\cline { 2 - 6 } & $16: 00-18: 00$ & $59 \pm 11 \mathrm{~b}$ & 30 & 0.0 & 3.7 \\
\hline \multirow{3}{*}{ Wind speed $\left(\mathrm{m} \mathrm{s}^{-1}\right)$} & $8: 00-10: 00$ & $0.2 \pm 0.4 \mathrm{~b}$ & 0 & 0.1 & 5.7 \\
\cline { 2 - 6 } & $12: 00-14: 00$ & $0.5 \pm 1.0 \mathrm{a}$ & 0 & 0.0 & 4.7 \\
\cline { 2 - 6 } & $16: 00-18: 00$ & $0.2 \pm 0.6 \mathrm{~b}$ & 0 & 0.0 & 39 \\
\hline
\end{tabular}

${ }^{1}$ Means followed by the same lower-case letters in the columns, for each variable, did not differ in the Bonferroni test, at $5 \%$ probability. 
Table 6. Average values (mean \pm standard deviation) of height $(\mathrm{cm})$ of forages and proportions $(\%)$ of grasses, legumes, senescent material and spontaneous in the different measure points.

\begin{tabular}{|c|c|c|c|c|c|}
\hline Points & Height & Grass & Legumes & Senescent & Spontaneous \\
\hline Under canopy & $11.3 \pm 5.4$ & $23.8 \pm 14.8$ & $2.4 \pm 7.3 \mathrm{~b}^{1}$ & $18.4 \pm 16.2$ & $55.6 \pm 21.3 \mathrm{a}$ \\
\hline Intermediate & $13.2 \pm 6.1$ & $32.0 \pm 18.2$ & $7.9 \pm 12.8 \mathrm{a}$ & $20.1 \pm 15.2$ & $40.4 \pm 23.5 \mathrm{~b}$ \\
\hline Full sun & $12.9 \pm 6.1$ & $28.9 \pm 16.9$ & $9.0 \pm 14.2 \mathrm{a}$ & $21.7 \pm 15.4$ & $40.3 \pm 22.3 \mathrm{~b}$ \\
\hline
\end{tabular}

${ }^{1}$ Means followed by the same lower-case letters in the columns, for each variable, did not differ in the Bonferroni test, at $5 \%$ probability.

\section{DISCUSSION}

This work demonstrated that the different microclimate conditions, according to the shading effect, influenced species distribution in the area, based on the leaf morphological characteristics. This is a preliminary result, characterized by a short-term study, due to the limitations regarding the periodicity of microclimate and forage sampling. However, even with a limited data, we found significant differences and important results which lead us to further confirmations. Our findings are particularly important because it is necessary to know what species might be suitable in the silvopastoral system, mainly considering agroecological handling. Many farmers introduced this system in their area, but they neglect that the tree provides shade, and if the pasture did not adapt to this condition, the result might be an area without pasture coverage.

\section{Microclimate}

Regarding the illuminance, our findings were similar to Gao et al. [2013], who evaluated the photosynthetically active radiation in an agroforestry system with Malus pumila M. (apple) associated with Glycine max L. Merr. (soybean) and Arachis hypogaea L. (peanut) at different distances from the trees. The authors verified that the radiation peak occurred at 13:00 and the minimum value at 17:00. In the same research, they found lower values of photosynthetically active radiation with a reduction of $17.9 \%$ in $0.5 \mathrm{~m}$ and $10.4 \%$ in $1.5 \mathrm{~m}$ for the system with apple and soybean and, $17.8 \%$ in $0.5 \mathrm{~m}$ and $5.4 \%$ in $1.5 \mathrm{~m}$ for the system with apple and peanut compared to the control treatment. Karki and Goodman [2010] found that solar radiation was lower under the canopy at dawn and late afternoon compared to the peak hours observed (11:00 to 14:00) in the silvopastoral system composed of Pinus taeda L.

Based on these results, we observed that the canopy architecture in an agroecological system intercepts solar radiation more efficiently under higher radiation peak during the day, that is, acting as filters or reflective material providing a higher level of shading. This result might explain the results obtained with illuminance demonstrated in Table 3.

From 8:00 to 10:00, we registered lower soil surface temperature under the canopy at $17.7^{\circ} \mathrm{C}$. In this daily period, the solar radiation is less intense, and the difference between under the canopy and the full sun inside the paddock was $1.9^{\circ} \mathrm{C}$. For the intermediate level, there was no difference when compared with under the canopy, which indicated the effect of the canopy in providing lower surface temperatures in a shaded area.

Throughout the year, there were changes in the maximum height of the sun, which generates spatial variation in the availability of solar radiation [Monteith and Unsworth, 2013]. This factor may have caused heterogeneity in the samples. The range from 12:00 to 14:00 was in the time interval when the sun is at its highest

Table 7. Average values (mean \pm standard deviation) of proportions (\%) of leaf, stem, senescent material and leaf/stem (1/s) ratio of grasses and legumes in different measure points.

\begin{tabular}{|c|c|c|c|c|c|c|c|c|}
\hline \multirow{2}{*}{ Points } & \multicolumn{4}{|c|}{ Grass } & \multicolumn{4}{c|}{ Legumes } \\
\cline { 2 - 10 } & Leaf & Stem & Senescent & I/s & Leaf & Stem & Senescent & $1 / \mathrm{s}$ \\
\hline Under canopy & $39.5 \pm 19.4 \mathrm{a}^{1}$ & $21.5 \pm 14.5$ & $38.6 \pm 23.8$ & $4.4 \pm 11.4 \mathrm{a}$ & $11.5 \pm 23.4$ & $14.4 \pm 27.1$ & $2.3 \pm 10.2$ & $0.2 \pm 0.5$ \\
\hline Intermediate & $36.4 \pm 17.2 \mathrm{~b}$ & $20.0 \pm 14.0$ & $34.5 \pm 21.8$ & $3.5 \pm 8.0 \mathrm{~b}$ & $17.5 \pm 23.2$ & $26.4 \pm 31.1$ & $3.1 \pm 10.4$ & $0.3 \pm 0.4$ \\
\hline Full sun & $32.5 \pm 16.0 \mathrm{~b}$ & $20.7 \pm 15.0$ & $37.7 \pm 24.0$ & $3.8 \pm 7.8 \mathrm{~b}$ & $18.5 \pm 23.1$ & $26.0 \pm 30.3$ & $2.5 \pm 8.8$ & $0.3 \pm 0.5$ \\
\hline
\end{tabular}

${ }^{1}$ Means followed by the same lower-case letters in the columns, for each variable, did not differ in the Bonferroni test, at $5 \%$ probability. 
point, which influences average soil surface temperatures. However, the point under the canopy showed a lower temperature when compared with others, whose range of values between this and the interme-diate collection point was $2.8^{\circ} \mathrm{C}$. The amplitude $\left(4.9^{\circ} \mathrm{C}\right)$ was evident between the point under the canopy and the full sun.

Ehret et al. [2018] assessed an agroforestry system, composed of different tree species, one meter away from the tree rows and in full sun and, they found temperatures of $15.8^{\circ} \mathrm{C}$ at $5 \mathrm{~cm}$ depth in the soil, while the full sun was $16.2{ }^{\circ} \mathrm{C}$. They observed that in the sub-forest, the photon flux density was lower compared to full sun, which decreases the soil temperature, evidencing the results found in the present study.

About the air temperature variation, the temperature on the Earth's surface is determined by the amount of radiant energy it receives from the sun (short waves) and terrestrial radiation (long waves). Therefore, this fact may explain the increase in temperature between 12:00 to 14:00, with $29.4{ }^{\circ} \mathrm{C}$ and reduction between $16: 00$ to 18:00, with $25.0^{\circ} \mathrm{C}$. Lopes et al. [2016] assessed the air temperature in two periods of the day (morning and afternoon) under the canopy, inside the paddock in full sun and among the rows in a silvopastoral system composed of Eucalyptus ssp intercropped with Brachiaria brizantha cv BRS Piatã and in adjacent pasture composed of the same forage species. The authors found averages of $30.8^{\circ} \mathrm{C}$ (morning) and $34.7^{\circ} \mathrm{C}$ (afternoon) under the canopy and values of $33.9^{\circ} \mathrm{C}$ (morning) and $37.6{ }^{\circ} \mathrm{C}$ (afternoon) in the full sun inside the paddock. The values obtained by the authors follow the same variability found in our study, mainly during morning and noon.

The variability in relative humidity had a direct relationship with the air temperature throughout the day. Air humidity is an essential factor for plant growth since it allows the stomata to remain open longer, allowing the necessary gas exchange, mainly for photosynthesis activity as well as for transpiration, essential for the absorption of water and nutrients by the roots. The wind speed found for the time 12:00 to 14:00 can be explained by the difference between the shaded areas and the full sun - which they can create a horizontal temperature gradient that causes distinct heating between shade and sun, generating locally advective breezes - and to the possible centralization of the wind by the tree rows [Bosi et al., 2020].

\section{Botanical composition}

The condition of the lowest illuminance reduces the nutrients, water absorption and carbohydrate production in the plant, which is important to survival and growth. Andrade et al. [2004], assessing different levels of shade on the production of two genotypes of Arachis pintoi K., observed that at the highest level of shading $(70 \%)$, legumes showed deficient growth, although the period evaluated is the dry season in which their performance is usually lower. The higher proportion of legumes in the full sun might be associated with the forage consumption of animals. This result was influenced by factors related to the structure of the forage canopy, mainly the ease of seizure and harvesting of forage during grazing [Oliveira et al., 2021]. Arachis pintoi K. and Trifolium ssp, with a low-growth habit, where the main legume species which were easily found in the experimental area.

The proportion of spontaneous species was higher under the canopy than in the full sun (Table 5). Ferreira [2012] evaluated the tree species of Mimosa scabrella Benth in the same experimental area of this study and found a lower frequency of spontaneous in full sun, with $5.13 \%$, than under shading of trees with $21.39 \%$.

Regarding the leaf proportions and leaf/stem ratio of grass, the light deficiency in plants can inhibit the growth and development [Choi et al., 2014; Scafidi et al., 2013; Wu et al., 2018] and change many physiological and biochemical characteristics as well as the changes in leaf morphological features as increasing the leaf area [Branco et al., 2017]. According to $\mathrm{Wu}$ et al. [2017], the shaded condition promotes the stimulus for multiplication and differentiation of cells, making the leaves more significant than for other parts.

The higher leaf area and leaf/stem ratio under the canopy were the physiological features used by grass to compensate for the lower illuminance avoiding a reduction in photosynthesis. These answers are according to the observations made by Pilau et al. [2015], with the proportion increase of ryegrass leaves under shade conditions provided by the Anadenanthera colubrina (Vell.) Brenan in the silvopastoral system. 


\section{CONCLUSION}

The different shading levels in an agroecological silvopastoral system affected the microclimate and botanical composition of polyphytic pasture. We registered lower illuminance and soil surface temperature under the canopy, especially in the hottest hours of the day. The air temperature was modified both by the level of shading and the assessed time intervals, and air humidity and wind speed were different in the measured hours. The levels of shading provided by the canopy influenced the proportions of legumes and spontaneous species in the area. Higher proportions of spontaneous species were observed under the canopy, which indicates the higher adaptability of these species to the shaded environment. The interception of radiation caused by the canopy influenced the botanical composition of the grass. Higher leaf proportions and higher leaf/stem ratio were obtained under shading.

\section{Acknowledgements}

The authors would like to thank the National Council for Scientific and Technological Development $(\mathrm{CNPq})$ for the financial support (Grant 457963/2014-0) and Centro Paranaense de Referência em Agroecologia (Paraná Center for Reference in Agroecology - CPRA), for the concession of the experimental area. They also thank the Coordination for the Improvement of Higher Education Personnel (CAPES) for granting a scholarship.

\section{REFERENCES}

1. Altieri M.B. 2018. Agroecology: The science of sustainable agriculture. CRC Press: Boca Raton.

2. Alvares C.A., Stape J.L., Sentelhas P.C., Gonçalves J.L.M., Sparovek G. 2014. Köppen's climate classification map for Brazil. Meteorologische Zeitschrift, 22, 711-728.

3. Andrade C.M.S., Valentin J.F., Carneiro J.C., Vaz F.A. 2004. Crescimento de gramíneas e leguminosas forrageiras tropicais sob sombreamento. Pesquisa Agropecuária Brasileira, 39, 263-270 (in Portuguese).

4. Bayat L., Arab M., Aliniaeifard S., Seif M., Lastochkina O., Li T. 2018. Effects of growth under different light spectra on the subsequent high light tolerance in rose plants. AoB Plants, 10, ply052.
5. Bosi C., Pezzopane J.R.M., Sentelhas P.C. 2020. Silvopastoral system with Eucalyptus as a strategy for mitigating the effects of climate change on Brazilian pasturelands. Anais da Academia Brasileira de Ciências, 92 (suppl.1), e20180425.

6. Branco M.C.S., Almeida A.A.F., Dalmolin A.C., Ahnert D., Baligar V.C. 2017. Influence of low light intensity and soil flooding on cacao physiology. Scientia Horticulturae, 217, 243-257.

7. Choi H.G., Moon B.Y., Kang N.J., Kwon J.K., Bekhzod K., Park S.P., Lee S.Y. 2014. Yield loss and quality degradation of strawberry fruits cultivated under the deficient insolation conditions by shading. Horticulture, Environment, and Biotechnology, 55, 263-270.

8. Ehret M., Graß R., Wachendorf M. 2018. Productivity at the tree-crop interface of a young willowgrassland alley cropping system. Agroforestry Systems, 92, 71-83.

9. Feldhake C.M. 2009. Forage evapotranspiration and photosynthetically active radiation interception in proximity to deciduous trees. Agricultural Water Management, 96, 1170-1174.

10. Ferreira T.L.A. 2012. Bracatinga (Mimosa scabrella) como componente arbóreo em pastagem polifitica sob Pastoreio Racional Voisin. MSc. Dissertation, Universidade Federal de Santa Catarina, Florianópolis (in Portuguese).

11. Gao L., Xu H., Bi H., Xi W., Bao B., Wang X., Bi C., Chang Y. 2013. Intercropping competition between apple trees and crops in agroforestry systems on the Loess Plateau of China. PLoS One, 8, e70739.

12. Jose S. \& Dollinger J. 2019. Silvopasture: a sustainable livestock production system. Agroforestry Systems, 93, 1-9.

13. Karki U. \& Goodman M.S. 2010. Cattle distribution and behaviour in southern-pine silvopastoral versus open-pasture. Agroforestry Systems, 78, 159-168.

14. Karvatte Jr.N., Miyagi E.S., Oliveira C.C., Mastelaro A.P., Coelho F.A., Bayma G., Bungenstab D.J., Alves F.V. 2021. Spatiotemporal variations on infrared temperature as a thermal comfort indicator for cattle under agroforestry systems. Journal of Thermal Biology, 97, 10287.

15. Lee O.E. \& Braun T.M. 2011. Permutation tests for random effects in linear mixed models. Biometrics, 68(2), 486-493.

16. Lopes L.B., Eckstein C., Pina D.S., Carnevalli R.A. 2016. The influence of trees on the thermal environment and behaviour of grazing heifers in Brazilian Midwest. Tropical Animal Health and Production, 48, 755-761.

17. Monteith J.L. \& Unsworth M.H. 2013. Principles of Environmental Physics: Plants, Animals, and the Atmosphere. Academic Press: Oxford. 
18. Murgueitio E.R., Chará J.O., Barahona R.R., Cuartas C.C.; Naranjo, J.R. 2014. Los sistemas silvopastoriles intensivos (SSPI), herramienta de mitigación y adaptación al cambio climático. Tropical and Subtropical Agroecosystems, 17, 501-507 (in Spanish).

19. Oliveira C.C., Almeida R.G., Karvatte Jr. N., Villela S.D.J., Bungenstab D.J., Alves F.V. 2021. Daytime ingestive behaviour of grazing heifers under tropical silvopastoral systems: Responses to shade and grazing management. Applied Animal Behaviour Science, 240, 105360.

20. Peri P.L., Dube F., Varela A.C. 2016. Silvopastoral systems in the subtropical and temperate zones of South America: an overview. In Silvopastoral systems in Southern South America. In Peri P.L., Dube F., Varela A.C., Eds. Springer: Gainesville.

21. Pilau J., Elli E.F., Nardino M., Korcelski C., Schmidt D., Caron B.O. 2015. Desenvolvimento e qualidade do azevém no sub-bosque de angico-vermelho em sistema silvipastoril. Comunicata Scientiae, 6, 437444 (in Portuguese).

22. Poppi D.P., Quigley S.P., Silva T.A.C.C., McLennan S.R. 2018. Challenges of beef cattle production from tropical pastures. Revista Brasileira de Zootecnia, 47, e20160419.

23. R Development Core Team. 2019. R: A language and environment for statistical computing. R Foundation for Statistical Computing, Vienna, Austria. Available online: URL http://www.R-project.org.

24. Scafidi P., Pisciotta A., Patti D., Tamborra P., Lorenzo R.D., Barbagallo M.G. 2013. Effect of artificial shading on the tannin accumulation and aromatic composition of the Grillo cultivar (Vitis vinifera L.). BMC Plant Biology, 13, 175.

25. Verbeke G. \& Molenberghs G. 2000. Linear mixed models for longitudinal data. Springer-Verlag, New York.

26. Vieira F.M.C., Deniz M., Vismara E.S., Herbut P., Pilatti J.A., Sponchiado M.Z., Puretz B.O. 2020. Thermoregulatory and behaviour responses of dairy heifers raised on a silvopastoral system in a subtropical climate. Annals of Animal Science, 20, 613-627.

27. Wall D.H. \& Six J. 2015. Give soils their due. Science, 13(6223), 695.

28. Wu Y., Gong W., Yang W. 2017. Shade Inhibits leaf size by controlling cell proliferation and enlargement in soybean. Scientific Reports, 7, 9259.

29. Wu Y., Qiu T., Shen Z., Wu Y., Lu D., He J. 2018. Effects of shading on leaf physiology and morphology in the 'Yinhong' grape plants. Revista Brasileira de Fruticultura, 40, e-037. 